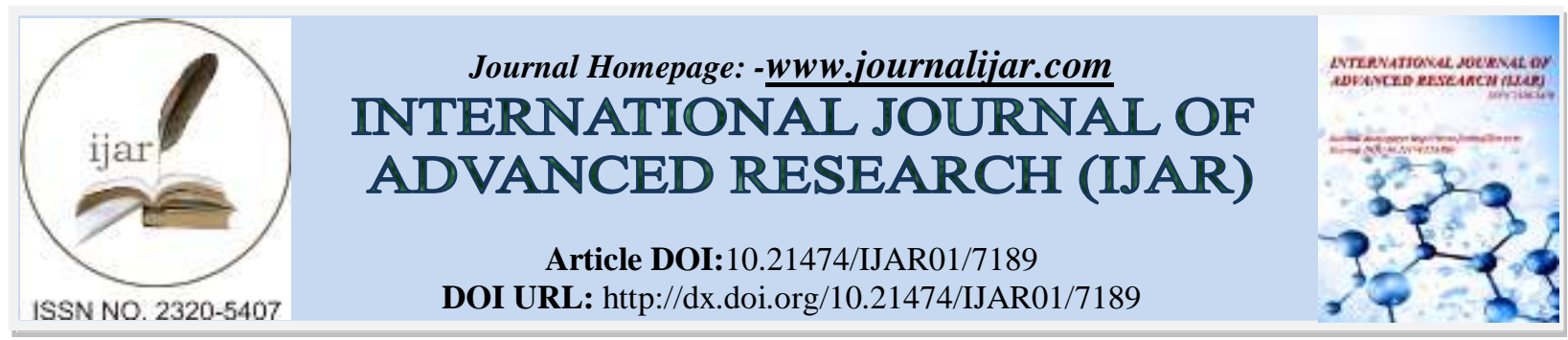

RESEARCH ARTICLE

\title{
IMPACT OF WOMEN EMPOWERMENT ON STANDARD OF LIVING.
}

\author{
Dr. S. Gunasekaran. \\ Professor, Centre for Applied Research, Gandhigram Rural Institute - Deemed to be University, Gandhigram-624 \\ 302, TamilNadu, India.
}

\section{Manuscript Info}

Manuscript History

Received: 02 April 2018

Final Accepted: 04 May 2018

Published: June 2018

Keywords:-

Empowerment, Dimension, Standard of Living, Association.

\section{Abstract}

The study based on a representative sample of 3600 women selected from three different districts of TamilNadu examines the association between the women empowerment status and standard of living. The women empowerment focuses on six different dimensions such as economic, socio-cultural, familial, legal, political and psychological; and the standard of living is assessed based on diet pattern, nutritional status of children, economic status, housing condition and attitude towards education of girl children. The results indicate a strong and positive association between women empowerment and standard of living in both the rural and urban areas of TamilNadu. The results suggest that women empowerment is playing a vital role in improving the standard of living of woman and the family as a whole.

Copy Right, IJAR, 2018,. All rights reserved.

\section{Introduction:-}

As women are an integral part of every economy, all round development and harmonious growth of a nation would be possible only when women are considered as equal partners in progress with men. However, in most developing countries, women have a low social and economic status. In such countries, effective empowerment of women is essential to harness the women labour in the mainstream of economic development. Any society which has achieved a high degree of social development has its women enjoying better status in terms of education, health, employment, participation in decision making in the family, community, State and civil society (Smita Mishra Panda, 2000). Gender equality is also desirable from an efficiency perspective: increases in opportunities for women lead to improvements in human development outcomes, poverty reduction, and potentially accelerated rates of economic growth. (Andrew Morrison et al., 2007). The empowerment of women covers both an individual and collective transformation. It strengthens their innate ability through acquiring knowledge, power and experience. It is central to the new package of the liberalization discourse, which transfers considerable responsibility of welfare to civil society. While initially efforts were launched in the name of emancipation, today the goal of national and international policies, development programmes and NGO activities seems to have shifted to achieving empowerment (Neera Burra et al., 2005).

The empowerment of women as a core issue was discussed in many International forums which include the world conference on Human Rights (Vienna, 1993), the International Conference on Population and Development (Cairo, 1994), the Fourth International Conference on Women (Beijing, 1995) and the World Health Assembly (Geneva, 1996). Further, it has been placed at the Centre of efforts to achieve gender equality and women's empowerment, 
inline with the agenda for sustainable development by2030 (UN, 2015). It is in this context, the present study aims to assess the impact of women empowerment on their standard of living in both the rural and urban areas of Tamil Nadu.

\section{Methodology:-}

The data for the present study has been taken from a large scale study conducted by the author with funding from the Ministry of Statistics and program Implementation, New Delhi on a representative sample of 3600 married women (aged 15-49years) selected from both the rural and areas of three different districts of TamilNadu viz., Madurai, Karur and Villupuram representing high, medium and low level of gender development districts respectively as per the TamilNadu Human Development Index (2003). The sample was selected based on multistage random sampling procedure. Initially, each district was grouped into two sampling domains such as rural and urban areas. Both the rural and urban sample were selected in two stages. The selection of Primary Sampling Units (PSUs) which are the villages in rural areas and wards in urban areas in the first stage followed by selection of respondents using systematic sampling procedure within each of the PSUs in the second stage. In total, six PSUs in rural areas and six PSUs in urban areas were selected in each of the three districts based on PPS sampling procedure.

A complete list of all married women (aged 15-49 years) who were the respondents for the survey was prepared for each PSU from the records maintained by the village health nurse / anganwadi workers served as the sampling frame for each of the selected PSUs. The sample for each PSUs is fixed at 100. In order to take care of non-response for various reasons, a 10 per cent over sampling was done. Of the 110 women selected using systematic sampling procedure, 100 women were interviewed in each of the selected PSUs. Thus a total of 600 women from each of the rural and urban areas in each district constitute the sample size for the study. In all the total sample size for each of the rural and urban area is 1800 .

\section{Measurement of Women Empowerment:-}

Many researchers have developed different measures of women empowerment on various dimensions at the individual and societal level. A Gender Empowerment Measure developed by Aasha Kapur Mehta (1996) focuses mainly three measures of gender empowerment based on the following indicators: representation in LokSabha, state legislatures, gram panchayats, panchayat samitis and zilla parishads; the literacy rate; exercise of the right to vote; life expectancy and income. Holding the Gender Development Index (GDI) and the Gender Empowerment Measure (GEM) devised by the UNDP to be unsatisfactory, Indira Hirway and Darshini Mahadevia(1996) present an alternative conceptual framework for measuring gender development in the south at the individual and societal levels and compute their Gender Development Measure (GDM) for major states in India. Malhotra Anju.et.al (2002) has developed different women development measure based on a list of the most commonly used dimensions of women's empowerment, drawing from the frameworks developed by various authors in different fields of social sciences. Allowing for overlap, these frameworks suggest that women's empowerment needs to occur along multiple dimensions including: economic, socio-cultural, familial/interpersonal, legal, political, and psychological. These six dimensions of women empowerment are adopted for the measurement of women empowerment (at individual level) in this study.

Accordingly, a set of women development indicators on each of these six domains were developed and placed on a three-point scale ranging from 0-2 for never, sometimes and always. The total score attained by each women is grouped in to three categories as low, medium and high based on percentile score. The total score attained by each woman for all six domains was clubbed together and grouped into the three categories as low medium and high in order to assesses the overall empowerment status of women.

\section{Measurement of Standard of Living:-}

The following five indicators of standard of living are considered for the present study.

\section{Diet pattern of the family:-}

A set of twenty food items were listed and the respondents were asked whether they had each of the food item at least once in the past one week before the survey. The responses were scored and the total score attained by each woman is used to assess their status of diet pattern.

Nutritional status of children under five years:-

Weight for age indicator is used to estimate the proportion of underweight children. 


\section{Household Amenities:-}

The economic status of the family is assessed indirectly based on the total score attained by women on their possession of certain essential household items.

\section{Housing condition:-}

Type of house and materials used for construction, sanitation facilities are assessed and used to determine the status of housing condition.

\section{Schooling of girl children:-}

The attitude of women on schooling of children mainly girl children is assessed in order to determine the value of girl children in the family.

\section{Results and Discussion:-}

The empowerment status of women on each of the six domains and the total empowerment combining all six domains are related with each of the five standard of living indicators of women and the chi-square test of significance is used to see the significance of the association between women empowerment and standard of living.

\section{Women Empowerment and diet pattern:-}

The results presented in table1 indicate that the economic empowerment of women in rural areas is exerting a negative effect on the diet pattern in the family. It is observed that the proportion of women who had good diet pattern decreased significantly with the increase in the level of economic empowerment in rural areas. May be, the rural women might be thinking of investing more on properties rather than on food items. However, in urban areas, the economic empowerment of women is not making any significant difference in the diet pattern of the family. The socio-cultural empowerment of women seems to increase the proportion of women who had good diet pattern in both the rural and urban areas. However, the differences are significant only in urban areas. Increase in the familial empowerment significantly increases the proportion of women who had good diet pattern in both the rural and urban areas. Interestingly, increase in the legal and psychological empowerment of women significantly increases the proportion of women who had good diet pattern in both the rural and urban areas. It is also very interesting to note that improvement in the overall empowerment status of women significantly improve the proportion of women who had good diet pattern in both the rural and urban areas. The results strongly support the hypothesis that empowerment of women leads to improved standard of living of the families and the women.

Table 1:-Percent distribution of women according to their diet pattern and empowerment status in various domains

\begin{tabular}{|c|c|c|c|c|c|c|c|c|}
\hline \multirow[t]{2}{*}{ Empowerment status } & \multicolumn{4}{|c|}{ Rural } & \multicolumn{4}{|c|}{ Urban } \\
\hline & $\mathbf{N}$ & Poor & Moderate & Good & $\mathbf{N}$ & Poor & Moderate & Good \\
\hline All & 1800 & 48.9 & 28.2 & 22.9 & 1800 & 36.2 & 28.2 & 35.6 \\
\hline $\begin{array}{l}\text { Economic } \\
\text { empowerment }\end{array}$ & & & & & & & & \\
\hline Low & 596 & 45.6 & 28.0 & 26.3 & 587 & 38.8 & 27.3 & 33.9 \\
\hline Medium & 669 & 45.9 & 32.4 & 21.7 & 676 & 34.6 & 28.7 & 36.7 \\
\hline High & 535 & 56.3 & 23.2 & 20.6 & 537 & 35.4 & 28.7 & 35.9 \\
\hline & & $\chi^{2}=22.315$ & $\mathrm{df}=4$ & $P \leq \mathbf{0 . 0 0 0}$ & & $\chi^{2}=2.703$ & $\mathrm{df}=4$ & $\mathrm{P} \leq 0.609$ \\
\hline $\begin{array}{l}\text { Socio-cultural } \\
\text { empowerment }\end{array}$ & & & & & & & & \\
\hline Low & 572 & 51.4 & 28.0 & 20.6 & 561 & 41.2 & 29.1 & 29.8 \\
\hline Medium & 672 & 49.4 & 27.8 & 22.8 & 689 & 34.5 & 27.3 & 38.2 \\
\hline High & 556 & 45.7 & 29.0 & 25.4 & 550 & 33.3 & 28.5 & 38.2 \\
\hline & & $\chi^{2}=4.861$ & $\mathrm{df}=4$ & $\mathrm{P} \leq 0.302$ & & $\chi^{2}=13.708$ & $\mathrm{df}=4$ & $\mathbf{P} \leq \mathbf{0 . 0 0 8}$ \\
\hline Familial empowerment & & & & & & & & \\
\hline Low & 590 & 54.1 & 25.6 & 20.3 & 576 & 44.8 & 24.7 & 30.6 \\
\hline Medium & 636 & 56.1 & 26.3 & 17.6 & 667 & 36.7 & 28.8 & 34.5 \\
\hline High & 574 & 35.5 & 33.1 & 31.4 & 557 & 26.8 & 31.2 & 42.0 \\
\hline & & $\chi^{2}=65.549$ & $\mathrm{df}=4$ & $P \leq 0.000$ & & $\chi^{2}=40.786$ & $\mathrm{df}=4$ & $\mathbf{P} \leq \mathbf{0 . 0 0 0}$ \\
\hline
\end{tabular}




\begin{tabular}{|l|c|c|c|c|c|c|c|c|}
\hline Legal empowerment & & & & & & & & \\
\hline Low & 569 & 66.6 & 20.6 & 12.8 & 520 & 56.2 & 25.6 & 18.3 \\
\hline Medium & 652 & 41.9 & 34.8 & 23.3 & 720 & 31.0 & 31.0 & 38.1 \\
\hline High & 579 & 39.4 & 28.3 & 32.3 & 560 & 24.5 & 27.1 & 48.4 \\
\hline & & $\chi^{2}=1.233 \mathrm{E} 2$ & $\mathrm{df}=4$ & $\mathbf{P} \leq \mathbf{0 . 0 0 0}$ & & $\chi^{2}=1.583 \mathrm{E} 2$ & $\mathrm{df}=4$ & $\mathbf{P} \leq \mathbf{0 . 0 0 0}$ \\
\hline Political empowerment & & & & & & & & \\
\hline Low & 148 & 61.5 & 23.6 & 14.9 & 191 & 50.3 & 24.1 & 25.7 \\
\hline Medium & 1053 & 47.2 & 28.2 & 24.6 & 1209 & 32.0 & 29.3 & 38.7 \\
\hline High & 599 & 48.7 & 29.4 & 21.9 & 400 & 42.2 & 27.0 & 30.8 \\
\hline & & $\chi^{2}=12.581$ & $\mathrm{df}=4$ & $\mathbf{P} \leq \mathbf{0 . 0 1 4}$ & & $\chi^{2}=33.426$ & $\mathrm{df}=4$ & $\mathbf{P} \leq \mathbf{0 . 0 0 0}$ \\
\hline $\begin{array}{l}\text { Psychological } \\
\text { empowerment }\end{array}$ & & & & & & & & \\
\hline Low & 489 & 54.6 & 30.7 & 14.7 & 418 & 31.8 & 35.4 & 32.8 \\
\hline Medium & 768 & 46.5 & 29.8 & 23.7 & 852 & 34.9 & 27.9 & 37.2 \\
\hline High & 543 & 47.1 & 23.8 & 29.1 & 530 & 41.9 & 23.0 & 35.1 \\
\hline & & $\chi^{2}=33.688$ & $\mathrm{df}=4$ & $\mathbf{P} \leq \mathbf{0 . 0 0 0}$ & & $\chi^{2}=21.719$ & $\mathrm{df}=4$ & $\mathbf{P} \leq \mathbf{0 . 0 0 0}$ \\
\hline Total empowerment & & & & & & & & \\
\hline Low & 614 & 54.7 & 26.2 & 19.1 & 566 & 45.1 & 29.0 & 26.0 \\
\hline Medium & 644 & 50.0 & 29.0 & 21.0 & 626 & 33.5 & 29.1 & 37.4 \\
\hline High & 542 & 41.0 & 29.5 & 29.5 & 608 & 30.8 & 26.6 & 42.6 \\
\hline & & $\chi^{2}=28.154$ & $\mathrm{df}=4$ & $\mathbf{P} \leq \mathbf{0 . 0 0 0}$ & & $\chi^{2}=42.938$ & $\mathrm{df}=4$ & $\mathbf{P} \leq \mathbf{0 . 0 0 0}$ \\
\hline & & & & & & & & \\
\hline
\end{tabular}

Women Empowerment and Nutritional status of Children:-

The results presented in Table2 indicate that the increase in empowerment status of women in legal aspects significantly increases the proportion of children with normal weight in both the rural and urban areas. The overall empowerment status of women also seems to have significantly associated with the nutritional status of children in rural areas. However, the empowerment status of women is not making any significant difference in the nutritional status of children in urban areas. Overall the results indicate that the proportion of normal children is comparatively low among women who have low empowerment status than the children of women who have medium and high level of empowerment.

Table 2:-Empowerment status of women and nutritional status of children below five years in both rural and urban areas

\begin{tabular}{|c|c|c|c|c|c|c|c|c|}
\hline \multirow[t]{3}{*}{ Empowerment Status } & \multicolumn{8}{|c|}{ Nutritional Status - Underweight } \\
\hline & \multicolumn{4}{|c|}{ Rural } & \multicolumn{4}{|c|}{ Urban } \\
\hline & $\mathbf{N}$ & $\begin{array}{l}\text { Below } \\
-3 \text { SD }\end{array}$ & $\begin{array}{l}\text { Below } \\
-2 \text { SD }\end{array}$ & Normal & $\mathbf{N}$ & $\begin{array}{l}\text { Below } \\
-3 \text { SD }\end{array}$ & $\begin{array}{l}\text { Below } \\
-2 \text { SD }\end{array}$ & Normal \\
\hline All & 433 & 15.7 & 34.6 & 65.4 & 448 & 11.8 & 33.3 & 66.7 \\
\hline \multicolumn{9}{|l|}{ Economic empowerment } \\
\hline Low & 187 & 16.6 & 34.8 & 65.2 & 207 & 13.5 & 34.8 & 65.2 \\
\hline Medium & 156 & 15.4 & 32.1 & 67.9 & 134 & 10.4 & 35.0 & 64.9 \\
\hline \multirow[t]{2}{*}{ High } & 90 & 14.4 & 38.9 & 61.1 & 107 & 10.3 & 28.0 & 72.0 \\
\hline & & $\chi^{2}=2.523$ & $\mathrm{df}=4$ & $\mathrm{P} \leq 0.640$ & & $\chi^{2}=2.828$ & $\mathrm{df}=4$ & $\mathrm{P} \leq 0.587$ \\
\hline \multicolumn{9}{|l|}{$\begin{array}{l}\text { Socio-Cultural } \\
\text { empowerment }\end{array}$} \\
\hline Low & 162 & 21.0 & 35.8 & 64.2 & 179 & 12.3 & 30.7 & 69.3 \\
\hline Medium & 142 & 12.0 & 33.1 & 66.9 & 154 & 12.3 & 39.6 & 60.4 \\
\hline \multirow[t]{2}{*}{ High } & 129 & 13.2 & 34.9 & 65.1 & 115 & 10.4 & 28.7 & 71.3 \\
\hline & & $\chi^{2}=7.085$ & $\mathrm{df}=4$ & $\mathrm{P} \leq 0.131$ & & $\chi^{2}=5.458$ & $\mathrm{df}=4$ & $\mathrm{P} \leq 0.243$ \\
\hline \multicolumn{9}{|l|}{$\begin{array}{l}\text { Familial / Interpersonal } \\
\text { empowerment }\end{array}$} \\
\hline Low & 126 & 18.3 & 33.3 & 66.7 & 159 & 10.1 & 32.7 & 67.3 \\
\hline
\end{tabular}




\begin{tabular}{|l|c|c|c|c|c|c|c|c|}
\hline Medium & 151 & 12.6 & 31.8 & 68.2 & 131 & 13.0 & 34.4 & 65.6 \\
\hline High & 156 & 16.7 & 38.5 & 61.5 & 158 & 12.7 & 32.9 & 67.1 \\
\hline & & $\chi^{2}=3.789$ & $\mathrm{df}=4$ & $\mathrm{P} \leq 0.435$ & & $\chi^{2}=0.902$ & $\mathrm{df}=4$ & $\mathrm{P} \leq 0.924$ \\
\hline Legal empowerment & & & & & & & & \\
\hline Low & 97 & 24.7 & 44.3 & 55.7 & 90 & 15.6 & 41.1 & 58.9 \\
\hline Medium & 136 & 16.2 & 36.0 & 64.0 & 179 & 14.5 & 34.1 & 65.9 \\
\hline High & 200 & 11.0 & 29.0 & 71.0 & 179 & 7.3 & 28.5 & 71.5 \\
\hline & & $\chi^{2}=10.465$ & $\mathrm{df}=4$ & $\mathbf{P} \leq \mathbf{0 . 0 3 3}$ & & $\chi^{2}=7.783$ & $\mathrm{df}=4$ & $\mathbf{P} \leq \mathbf{0 . 1 0 0}$ \\
\hline Political empowerment & & & & & & & & \\
\hline Low & 38 & 15.8 & 31.6 & 68.4 & 46 & 6.5 & 34.8 & 65.2 \\
\hline Medium & 288 & 15.3 & 35.1 & 64.9 & 313 & 12.5 & 33.5 & 66.5 \\
\hline High & 107 & 16.8 & 34.6 & 65.4 & 89 & 12.4 & 31.5 & 68.5 \\
\hline & & $\chi^{2}=0.570$ & $\mathrm{df}=4$ & $\mathrm{P} \leq 0.966$ & & $\chi^{2}=2.529$ & $\mathrm{df}=4$ & $\mathrm{P} \leq 0.639$ \\
\hline Psychological empowerment & & & & & & & & \\
\hline Low & 128 & 14.8 & 40.6 & 59.4 & 106 & 11.3 & 30.2 & 69.8 \\
\hline Medium & 196 & 16.8 & 30.6 & 69.4 & 230 & 11.3 & 32.2 & 67.8 \\
\hline High & 109 & 14.7 & 34.9 & 65.1 & 112 & 13.4 & 38.4 & 61.6 \\
\hline & & $\chi^{2}=7.495$ & $\mathrm{df}=4$ & $\mathrm{P} \leq 0.042$ & & $\chi^{2}=1.965$ & $\mathrm{df}=4$ & $\mathrm{P} \leq 0.742$ \\
\hline Total empowerment & & & & & & & & \\
\hline Low & 158 & 23.4 & 41.8 & 58.2 & 173 & 13.3 & 36.4 & 63.6 \\
\hline Medium & 148 & 11.5 & 32.4 & 67.6 & 133 & 10.5 & 29.3 & 70.7 \\
\hline High & 127 & 11.0 & 28.3 & 71.7 & 142 & 11.3 & 33.1 & 66.9 \\
\hline & & $\chi^{2}=12.062$ & $\mathrm{df}=4$ & $\mathbf{P} \leq \mathbf{0 . 0 1 7}$ & & $\chi^{2}=1.782$ & $\mathrm{df}=4$ & $\mathrm{P} \leq 0.776$ \\
\hline & & & & & & & & \\
\hline
\end{tabular}

Footnote: Below -2SD indicates Malnourished and below-3SDindicates severely Malnourished

\section{Women Empowerment and Household Amenities:-}

The results on the empowerment status of women and its impact on household amenities presented in table 3 indicate that increase in economic empowerment status of women decrease the level of household amenities in both the rural and urban areas. This may be due to the reason that women empowered in economic aspects might be investing more in savings and properties rather than spending on household amenities. The increase in the socio-cultural and familial empowerment of women significantly increases their level of household amenities in both the rural and urban areas. In rural areas, the proportion of women with good level of household amenities increased significantly from 18.2 per cent among women who had low empowerment status to 29.1 per cent among women who had high empowerment status in socio-cultural aspects. In urban areas, the increase in proportion of women with good level of household amenities is from 38.5 per cent to 48.2 per cent. In the case of familial empowerment, the proportion of women with good level of household amenities increased significantly from 18.8 per cent among low empowerment status women to 29.1 per cent among high empowerment status women in rural areas. Similar results observed for urban areas with an increase of 7.6percentage points from low (38.2 per cent) to high (45.8 per cent) level of empowerment.

In the case of legal empowerment, the proportion of women with good level of household amenities significantly increased from just 9.5 per cent among women who had low empowerment status to 34.2 per cent among women who had high empowerment status. A similar pattern of increase is observed among women in urban areas also with an increase of 28.8 percentage points from 29.4percent among women who had low empowerment status to 58.2 per cent among women who had high empowerment status. Though political empowerment is making a significant difference in the possession of household amenities, the pattern is not uniform in both the rural and urban areas.

Psychological empowerment of women is making a significant difference in the possession of household amenities in both the rural and urban areas. The proportion of women with good level of household amenities significantly and consistently increased with the increase in the psychological empowerment of women in both the rural and urban areas. In rural areas, the proportion increase is from 12.7 per cent among women who had low level of psychological empowerment to 31.3 per cent among women who had high level of psychological empowerment. In urban areas, the improvement is from 29.7 per cent to 50.2 per cent from low to high level of psychological empowerment 
Table 3:-Percent distribution of women according to their level of household amenities and empowerment level in each domain.

\begin{tabular}{|c|c|c|c|c|c|c|c|c|}
\hline \multirow[t]{2}{*}{ Empowerment level } & \multicolumn{4}{|c|}{ Rural } & \multicolumn{4}{|c|}{ Urban } \\
\hline & $\mathbf{N}$ & Poor & Moderate & Good & $\mathbf{N}$ & Poor & Moderate & Good \\
\hline All & 1800 & 44.7 & 33.2 & 22.1 & 1800 & 26.2 & 31.8 & 42.0 \\
\hline \multicolumn{9}{|l|}{$\begin{array}{l}\text { Economic } \\
\text { empowerment }\end{array}$} \\
\hline Low & 596 & 36.4 & 36.6 & 27.0 & 587 & 24.9 & 31.5 & 43.6 \\
\hline Medium & 669 & 43.8 & 35.1 & 21.1 & 676 & 21.9 & 35.5 & 42.6 \\
\hline \multirow[t]{2}{*}{ High } & 535 & 55.1 & 27.1 & 17.8 & 537 & 33.0 & 27.4 & 39.7 \\
\hline & & $\chi^{2}=42.517$ & $\mathrm{df}=4$ & $\mathrm{P} \leq \mathbf{0 . 0 0 0}$ & & $\chi^{2}=21.924$ & $\mathrm{df}=4$ & $\mathrm{P} \leq \mathbf{0 . 0 0 0}$ \\
\hline \multicolumn{9}{|l|}{$\begin{array}{l}\text { Socio-cultural } \\
\text { empowerment }\end{array}$} \\
\hline Low & 572 & 48.6 & 33.2 & 18.2 & 561 & 29.1 & 32.4 & 38.5 \\
\hline Medium & 672 & 45.8 & 34.7 & 19.5 & 689 & 25.0 & 35.0 & 40.1 \\
\hline \multirow[t]{2}{*}{ High } & 556 & 39.4 & 31.5 & 29.1 & 550 & 24.7 & 27.1 & 48.2 \\
\hline & & $\chi^{2}=25.115$ & $\mathrm{df}=4$ & $\mathrm{P} \leq \mathbf{0 . 0 0 0}$ & & $\chi^{2}=15.952$ & $\mathrm{df}=4$ & $\mathrm{P} \leq \mathbf{0 . 0 0 3}$ \\
\hline \multicolumn{9}{|l|}{ Familial empowerment } \\
\hline Low & 590 & 43.1 & 38.1 & 18.8 & 576 & 30.6 & 31.2 & 38.2 \\
\hline Medium & 636 & 49.2 & 32.1 & 18.7 & 667 & 23.8 & 33.9 & 42.3 \\
\hline \multirow[t]{2}{*}{ High } & 574 & 41.5 & 29.4 & 29.1 & 557 & 24.4 & 29.8 & 45.8 \\
\hline & & $\chi^{2}=30.539$ & $\mathrm{df}=4$ & $\mathbf{P} \leq \mathbf{0 . 0 0 0}$ & & $\chi^{2}=11.827$ & $\mathrm{df}=4$ & $P \leq 0.019$ \\
\hline \multicolumn{9}{|l|}{ Legal empowerment } \\
\hline Low & 569 & 62.6 & 27.9 & 9.5 & 520 & 39.2 & 31.3 & 29.4 \\
\hline Medium & 652 & 39.4 & 38.3 & 22.2 & 720 & 24.4 & 36.9 & 38.6 \\
\hline \multirow[t]{2}{*}{ High } & 579 & 33.2 & 32.6 & 34.2 & 560 & 16.2 & 25.5 & 58.2 \\
\hline & & $\chi^{2}=1.513 \mathrm{E} 2$ & $\mathrm{df}=4$ & $\mathrm{P} \leq \mathbf{0 . 0 0 0}$ & & $\chi^{2}=1.253 \mathrm{E} 2$ & $\mathrm{df}=4$ & $\mathrm{P} \leq \mathbf{0 . 0 0 0}$ \\
\hline \multicolumn{9}{|l|}{ Political empowerment } \\
\hline Low & 148 & 53.4 & 25.0 & 21.6 & 191 & 26.2 & 36.6 & 37.2 \\
\hline Medium & 1053 & 43.2 & 33.2 & 23.6 & 1209 & 24.3 & 32.5 & 43.2 \\
\hline \multirow[t]{2}{*}{ High } & 599 & 45.2 & 35.2 & 19.5 & 400 & 31.8 & 27.2 & 41.0 \\
\hline & & $\chi^{2}=9.600$ & $\mathrm{df}=4$ & $\mathrm{P} \leq \mathbf{0 . 0 4 8}$ & & $\chi^{2}=12.104$ & $\mathrm{df}=4$ & $\mathrm{P} \leq \mathbf{0 . 0 1 7}$ \\
\hline \multicolumn{9}{|l|}{$\begin{array}{l}\text { Psychological } \\
\text { empowerment }\end{array}$} \\
\hline Low & 489 & 56.0 & 31.3 & 12.7 & 418 & 31.3 & 39.0 & 29.7 \\
\hline Medium & 768 & 45.4 & 33.1 & 21.5 & 852 & 25.5 & 31.5 & 43.1 \\
\hline \multirow[t]{2}{*}{ High } & 543 & 33.5 & 35.2 & 31.3 & 530 & 23.2 & 26.6 & 50.2 \\
\hline & & $\chi^{2}=71.180$ & $\mathrm{df}=4$ & $\mathrm{P} \leq \mathbf{0 . 0 0 0}$ & & $\chi^{2}=41.357$ & $\mathrm{df}=4$ & $\mathrm{P} \leq \mathbf{0 . 0 0 0}$ \\
\hline \multicolumn{9}{|l|}{ Total empowerment } \\
\hline Low & 614 & 48.2 & 35.3 & 16.4 & 566 & 33.2 & 33.6 & 33.2 \\
\hline Medium & 644 & 46.7 & 33.9 & 19.4 & 626 & 22.8 & 35.5 & 41.7 \\
\hline \multirow[t]{2}{*}{ High } & 542 & 38.4 & 30.1 & 31.5 & 608 & 23.0 & 26.3 & 50.7 \\
\hline & & $\chi^{2}=42.603$ & $\mathrm{df}=4$ & $\mathrm{P} \leq \mathbf{0 . 0 0 0}$ & & $\chi^{2}=45.871$ & $\mathrm{df}=4$ & $\mathrm{P} \leq \mathbf{0 . 0 0 0}$ \\
\hline
\end{tabular}

The overall empowerment status of women shows a significantly positive effect in the level of household amenities in both the rural and urban areas. It is observed that in rural areas, the proportion of women with good level of household amenities increased from 16.4 per cent among women who had low level of empowerment to 31.5 per cent among women who had high level of empowerment. In urban areas, the increase is from 33.2 per cent to 50.7 per cent for low to high level of empowerment. The results strongly support the notion that the empowerment of women is a strong prelude for improvement in the economic status of the family as measured by the level of household amenities in both the rural and urban areas. 


\section{Women Empowerment and housing status:-}

The results presented in table4 indicate that economic empowerment of women is not making any significant difference in the housing status in both the rural and urban areas. The socio-cultural empowerment of women is also not making any significant difference in the housing status in rural areas. However, in urban areas, the proportion of women who had poor housing condition has decreased significantly with the increase in the empowerment of women on socio-cultural aspects. Familial empowerment and legal empowerment of women significantly associated with the housing status. It is observed that the proportion of women who had poor housing condition decreased with the increase in empowerment of women in familial and legal aspects in both the rural and urban areas. In rural areas, proportion of women who had poor housing condition decreased significantly from 45.1 per cent to 30.8 per cent for low to high level of familial empowerment of women. In urban areas, the decrease is from 31.1 per cent to 20.6 per cent. In the case of legal empowerment, the proportion of women reported to have poor housing condition significantly decreased from 47.1 per cent to 29.7 per cent with the increase in the empowerment level of women from low to high in the rural areas. In urban areas also, the decrease is observed to be significant with the decline of poor housing condition from 35.4 per cent to just 16.2 per cent for low to high level of empowerment. Though the political empowerment of women is making significant difference in the housing status in rural areas, the difference is not showing a clear pattern. In urban areas, the political empowerment is not making any significant difference in the housing status.

The psychological empowerment of women is indeed a significant factor in making difference in the housing status of women in both the rural and urban areas. The increase in the empowerment of women in psychological aspects significantly decrease the proportion of women who had poor housing condition and increase the proportion of women who had good housing condition in both the rural and urban areas.

Table 4:-Percent distribution of women according to their housing status and empowerment level in each domain

\begin{tabular}{|c|c|c|c|c|c|c|c|c|}
\hline \multirow[t]{2}{*}{ Empowerment Level } & \multicolumn{4}{|c|}{ Rural } & \multicolumn{4}{|c|}{ Urban } \\
\hline & $\mathbf{N}$ & Poor & Average & Good & $\mathbf{N}$ & Poor & Average & Good \\
\hline All & 1800 & 37.9 & 34.2 & 27.9 & 1800 & 26.0 & 35.4 & 38.6 \\
\hline \multicolumn{9}{|l|}{ Economic empowerment } \\
\hline Low & 596 & 36.4 & 34.2 & 29.4 & 587 & 23.7 & 37.1 & 39.2 \\
\hline Medium & 669 & 39.8 & 31.8 & 28.4 & 676 & 25.6 & 33.6 & 40.8 \\
\hline \multirow[t]{2}{*}{ High } & 535 & 37.2 & 37.0 & 25.8 & 537 & 29.1 & 35.9 & 35.0 \\
\hline & & $\chi^{2}=4.722$ & $\mathrm{df}=4$ & $\mathrm{P} \leq 0.317$ & & $\chi^{2}=7.073$ & $\mathrm{df}=4$ & $\mathrm{P} \leq 0.132$ \\
\hline \multicolumn{9}{|l|}{$\begin{array}{l}\text { Socio cultural } \\
\text { empowerment }\end{array}$} \\
\hline Low & 572 & 39.7 & 33.9 & 26.4 & 561 & 27.6 & 36.7 & 35.7 \\
\hline Medium & 672 & 38.4 & 34.2 & 27.4 & 689 & 26.7 & 30.8 & 42.5 \\
\hline \multirow[t]{2}{*}{ High } & 556 & 35.4 & 34.4 & 30.2 & 550 & 23.5 & 40.0 & 36.5 \\
\hline & & $\chi^{2}=3.027$ & $\mathrm{df}=4$ & $\mathrm{P} \leq 0.553$ & & $\chi^{2}=14.423$ & $\mathrm{df}=4$ & $P \leq 0.006$ \\
\hline \multicolumn{9}{|l|}{ Familial empowerment } \\
\hline Low & 590 & 45.1 & 28.8 & 26.1 & 576 & 31.1 & 31.4 & 37.5 \\
\hline Medium & 636 & 37.6 & 33.8 & 28.6 & 667 & 26.1 & 33.1 & 40.8 \\
\hline \multirow[t]{2}{*}{ High } & 574 & 30.8 & 40.1 & 29.1 & 557 & 20.6 & 42.4 & 37.0 \\
\hline & & $\chi^{2}=27.533$ & $\mathrm{df}=4$ & $\mathbf{P} \leq \mathbf{0 . 0 0 0}$ & & $\chi^{2}=24.400$ & $\mathrm{df}=4$ & $\mathbf{P} \leq \mathbf{0 . 0 0 0}$ \\
\hline \multicolumn{9}{|l|}{ Legal empowerment } \\
\hline Low & 569 & 47.1 & 34.8 & 18.1 & 520 & 35.4 & 34.4 & 30.2 \\
\hline Medium & 652 & 37.1 & 35.4 & 27.5 & 720 & 26.8 & 36.0 & 37.2 \\
\hline \multirow[t]{2}{*}{ High } & 579 & 29.7 & 32.1 & 38.2 & 560 & 16.2 & 35.7 & 48.0 \\
\hline & & $\chi^{2}=65.597$ & $\mathrm{df}=4$ & $\mathbf{P} \leq \mathbf{0 . 0 0 0}$ & & $\chi^{2}=61.309$ & $\mathrm{df}=4$ & $P \leq \mathbf{0 . 0 0 0}$ \\
\hline \multicolumn{9}{|l|}{ Political empowerment } \\
\hline Low & 148 & 43.9 & 27.0 & 29.1 & 191 & 30.4 & 31.9 & 37.7 \\
\hline Medium & 1053 & 33.8 & 34.8 & 31.4 & 1209 & 24.2 & 36.1 & 39.8 \\
\hline \multirow[t]{2}{*}{ High } & 599 & 43.6 & 34.9 & 21.5 & 400 & 29.5 & 35.2 & 35.2 \\
\hline & & $\chi^{2}=27.021$ & $\mathrm{df}=4$ & $\mathrm{P} \leq \mathbf{0 . 0 0 0}$ & & $\chi^{2}=7.315$ & $\mathrm{df}=4$ & $\mathrm{P} \leq 0.120$ \\
\hline Psychological & & & & & & & & \\
\hline
\end{tabular}




\begin{tabular}{|l|c|c|c|c|c|c|c|c|}
\hline empowerment & & & & & & & & \\
\hline Low & 489 & 39.7 & 35.8 & 24.5 & 418 & 28.7 & 37.8 & 33.5 \\
\hline Medium & 768 & 37.0 & 35.7 & 27.3 & 852 & 26.8 & 34.0 & 39.2 \\
\hline High & 543 & 37.6 & 30.6 & 31.9 & 530 & 22.6 & 35.8 & 41.5 \\
\hline & & $\chi^{2}=8.643$ & $\mathrm{df}=4$ & $\mathrm{P} \leq 0.071$ & & $\chi^{2}=8.893$ & $\mathrm{df}=4$ & $\mathrm{P} \leq 0.064$ \\
\hline Total empowerment & & & & & & & & \\
\hline Low & 614 & 42.2 & 32.2 & 25.6 & 566 & 31.1 & 35.5 & 33.4 \\
\hline Medium & 644 & 39.1 & 35.6 & 25.3 & 626 & 26.2 & 31.6 & 42.2 \\
\hline High & 542 & 31.5 & 34.7 & 33.8 & 608 & 21.1 & 39.3 & 39.6 \\
\hline & & $\chi^{2}=19.474$ & $\mathrm{df}=4$ & $\mathbf{P} \leq \mathbf{0 . 0 0 1}$ & & $\chi^{2}=22.741$ & $\mathrm{df}=4$ & $\mathbf{P} \leq \mathbf{0 . 0 0 0}$ \\
\hline
\end{tabular}

The overall total empowerment status of women is found to have significantly associated with the housing condition in both the rural and urban areas. The increase in empowerment of women significantly decrease the proportion of women who had poor housing condition and increase those who had good housing condition in both the rural and urban areas. The results strongly support the hypothesis that empowerment of women is an essential element in improving the standard of living as measured by the housing status of the family in both the rural and urban areas.

\section{Women Empowerment and Attitude towards girls' education:-}

The effect of empowerment status of women on their attitude towards girls' education presented in Table 5 revealed that economic empowerment of women is indeed making a significant difference in the attitude of women towards girls' education in both the rural and urban areas. However, the differences are not showing any specific direction of change. The socio-cultural empowerment is not making any significant difference in the

Table 5:-Percent distribution of women according to their attitude towards girls education and level of empowerment in each domain

\begin{tabular}{|c|c|c|c|c|c|c|}
\hline \multirow[t]{2}{*}{ Empowerment } & \multicolumn{3}{|c|}{ Rural } & \multicolumn{3}{|c|}{ Urban } \\
\hline & $\mathbf{N}$ & Low & High & $\mathbf{N}$ & Low & High \\
\hline All & 1800 & 17.9 & 82.1 & 1800 & 16.1 & 83.9 \\
\hline \multicolumn{7}{|c|}{ Economic empowerment } \\
\hline Low & 596 & 17.4 & 82.6 & 587 & 21.3 & 78.7 \\
\hline Medium & 669 & 14.3 & 85.7 & 676 & 12.1 & 87.9 \\
\hline \multirow[t]{2}{*}{ High } & 535 & 23.0 & 77.0 & 537 & 15.3 & 84.7 \\
\hline & $\chi^{2}=15.222$ & $\mathrm{df}=2$ & $\mathrm{P} \leq \mathbf{0 . 0 0 0}$ & $\chi^{2}=19.929$ & $\mathrm{df}=2$ & $\mathbf{P} \leq \mathbf{0 . 0 0 0}$ \\
\hline \multicolumn{7}{|c|}{ Socio-cultural empowerment } \\
\hline Low & 572 & 19.4 & 80.6 & 561 & 22.8 & 77.2 \\
\hline Medium & 672 & 17.0 & 83.0 & 689 & 12.8 & 87.2 \\
\hline \multirow[t]{2}{*}{ High } & 556 & 17.6 & 82.4 & 550 & 13.3 & 86.7 \\
\hline & $\chi^{2}=1.306$ & $\mathrm{df}=2$ & $\mathrm{P} \leq 0.520$ & $\chi^{2}=27.698$ & $\mathrm{df}=2$ & $\mathrm{P} \leq \mathbf{0 . 0 0 0}$ \\
\hline \multicolumn{7}{|l|}{ Familial empowerment } \\
\hline Low & 590 & 17.5 & 82.5 & 576 & 21.9 & 78.1 \\
\hline Medium & 636 & 18.7 & 81.3 & 667 & 15.0 & 85.0 \\
\hline \multirow[t]{2}{*}{ High } & 574 & 17.6 & 82.4 & 557 & 11.3 & 88.7 \\
\hline & $\chi^{2}=0.396$ & $\mathrm{df}=2$ & $\mathrm{P} \leq 0.820$ & $\chi^{2}=24.337$ & $\mathrm{df}=2$ & $P \leq 0.000$ \\
\hline \multicolumn{7}{|l|}{ Legal empowerment } \\
\hline Low & 569 & 32.9 & 67.1 & 520 & 34.2 & 65.8 \\
\hline Medium & 652 & 13.0 & 87.0 & 720 & 12.4 & 87.6 \\
\hline \multirow[t]{2}{*}{ High } & 579 & 8.8 & 91.2 & 560 & 3.9 & 96.1 \\
\hline & $\chi^{2}=1.295 \mathrm{E} 2$ & $\mathrm{df}=2$ & $P \leq 0.000$ & $\chi^{2}=1.958 \mathrm{E} 2$ & $\mathrm{df}=2$ & $P \leq 0.000$ \\
\hline \multicolumn{7}{|l|}{ Political empowerment } \\
\hline Low & 148 & 23.0 & 77.0 & 520 & 34.2 & 65.8 \\
\hline Medium & 1053 & 16.3 & 83.7 & 720 & 12.4 & 87.6 \\
\hline \multirow[t]{2}{*}{ High } & 599 & 19.5 & 80.5 & 560 & 3.9 & 96.1 \\
\hline & $\chi^{2}=5.422$ & $\mathrm{df}=2$ & $\mathrm{P} \leq 0.066$ & $\chi^{2}=1.958 \mathrm{E} 2$ & $\mathrm{df}=2$ & $\mathrm{P} \leq \mathbf{0 . 0 0 0}$ \\
\hline Psychological empowe & & & & & & \\
\hline
\end{tabular}




\begin{tabular}{|l|c|c|c|c|c|c|}
\hline Low & 489 & 26.4 & 73.6 & 191 & 23.6 & 76.4 \\
\hline Medium & 768 & 17.1 & 82.9 & 1209 & 15.1 & 84.9 \\
\hline High & 543 & 11.6 & 88.4 & 400 & 15.5 & 84.5 \\
\hline & $\chi^{2}=38.878$ & $\mathrm{df}=2$ & $\mathbf{P} \leq \mathbf{0 . 0 0 0}$ & $\chi^{2}=8.973$ & $\mathrm{df}=2$ & $\mathrm{P} \leq 0.011$ \\
\hline Total empowerment & & & & & & \\
\hline Low & 614 & 21.2 & 78.8 & 566 & 27.2 & 72.8 \\
\hline Medium & 644 & 17.1 & 82.9 & 626 & 12.9 & 87.1 \\
\hline High & 542 & 15.3 & 84.7 & 608 & 8.9 & 91.1 \\
\hline & $\chi^{2}=7.219$ & $\mathrm{df}=2$ & $\mathbf{P} \leq \mathbf{0 . 0 2 7}$ & $\chi^{2}=79.964$ & $\mathrm{df}=2$ & $\mathbf{P} \leq \mathbf{0 . 0 0 0}$ \\
\hline
\end{tabular}

attitude of women towards girl's education in rural areas. However, in urban areas, improvement in the sociocultural empowerment of women makes significant increase in the proportion of women who had high level of positive attitude towards girls' education. Familial empowerment is not making any significant difference in the attitude of women towards girls' education in rural areas. However, in urban areas, increase in the level of familial empowerment significantly increases the proportion of women who had high level of positive attitude towards girls' education. Increase in the level of legal empowerment makes significant increase in the proportion of women who had high level of positive attitude towards girl's education. Political empowerment is making significantly positive influence in urban areas only. Psychological empowerment is observed to have significantly positive influence on the attitude of women towards girl's education. Though there are domain wise variation in the influence of women empowerment on their attitude towards girl's education, the overall empowerment status of women shows that the proportion of women who had high level of positive attitude towards girl's education increased significantly with every increase in the level of empowerment of women in both the rural and urban areas. On the whole, the results indicate that empowerment of women is having significantly positive effect on the attitude of women towards girls' education in both the rural and urban areas.

\section{Conclusion:-}

The results of the study indicate that though there are variation on the effect of women empowerment on standard of living, the overall empowerment status of women positively and significantly associated with their standard of living as measured by their diet pattern, nutritional status of children, economic status (household amenities), housing condition and attitude towards girl's education. The results strongly support the hypothesis that empowerment of women leads to improved standard of living of the family and the women. Hence it is concluded that the empowerment of women is an integral part of development process and there is a need for the Government to evolve suitable policies and programmes at micro level in the aforesaid six dimensions of empowerment in order to achieve the goal of Gender Equality and Women Empowerment by 2030as envisaged in the United Nations Sustainable Development Goals.

\section{References:-}

1. Aasha Kapur Mehta(1996).Recasting Indices for Developing Countries-A Gender Empowerment Measure. Economics and Political weekly. Vol - XXXI No. 43, October 26, 1996.

2. Andrew Morrison,Dhushyanth Raju and Nistha Sinha (2007). Gender Equality, Poverty and Economic Growth. policy research working paper 4349. The world bank gender and development group Poverty Reduction and Economic Management Network: September 2007.

3. Beijing Documents (1995). The Agenda for Women's Empowerment. Populi, 22:8, December, 1995.

4. Cairo (1994). International Conference on Population and Development(ICPD), Cairo, Egypt.

5. Geneva (1996). Forty ninth World Health Assembly, Geneva, 20-25, May, WHA 49.12 WHO Global Strategy for Occupational Health for all.

6. Indira Hirway and Darshini Mahadevia, (1996). "Critique of Gender Development Index: Towards an Alternative". Economic and Political Weekly. Vol. 31, No. 43 (Oct. 26, 1996), pp. WS87-WS96

7. Malhotra Anju, Sidney Ruth Schuler, Carol Boender, (2002). "Measuring Women's Empowerment as a Variable in International Development".Background Paper Prepared for the World Bank Workshop on Poverty and Gender: New Perspectives. Final Version: June 28, 2002.

8. Neera Burra, Joy Deshmukh-Ranadive and Ranjani K. Murthy. (2005). 'Micro-Credit, Poverty and Empowerment - Linking the Triad'. Sage Publications, New Delhi.

9. Smita Mishra Panda. (2000). 'Women's Empowerment through NGO Interventions: A frame work for assessment'. Social change issues and perspectives, $30: 3 \& 4$, pp. $44-63$. 
10. UN (2015). 'UN Sustainable Development Goals'. United Nations Headquarters, NY.

11. Vienna (1993). World Conference on Human Rights. Vienna Declaration and Programme of Action. 14-25 June. General Assembly, United Nations A/CONF 157/

12. Footnote: Below five indicates Malnourished and below five indicates severely Malnourished 